\title{
Techniques of Special Collections
}

\author{
A PRECONFERENCE OF THE \\ RARE BOOKS SECTION \\ ASSOCIATION OF COLLEGE AND RESEARCH LIBRARIES \\ A DIVISION OF THE \\ AMERICAN LIBRARY ASSOCIATION
}

Place: Stanford University, Stanford, California

Dates: June 22-24, 1967

Program:

Thursday, June 22

2:00 p.m. Registration

Exhibition, Bender Room, Stanford University

6:00 p.m. Reception and dinner

Friday, June 23

10:00 a.m. "Methods of disposing of duplicate and unwanted material" -panel discussion

12:30 p.m. Luncheon. Speaker to be announced

2:00 p.m. Exhibition techniques-panel discussion

6:30 p.m. Reception and dinner

Speaker: Richard Dillon, Librarian, Sutro Library, San Francisco

Saturday, June 24

9:30 a.m. "Valuation and appraisal"-panel discussion.

12:00 noon Luncheon

1:30 p.m. Buses to San Francisco

2:00 p.m. Tour of San Francisco libraries

6:00 p.m. Reception

Rooms will be available in the dormitories of Stanford University for the nights of June 22 and 23 . The conference fee will be announced in a future issue of "CRL News" and will include registration fee and meals. Registration will be limited.

Additional information and registration forms will be available from the ACRL Executive Secretary, 50 E. Huron Street, Chicago 60611, after April 1. A mailing will be made to all members of the Rare Books Section at that time and will include registration forms. 